\title{
La Via Pulchritudinis, sacramento del encuentro con Dios ${ }^{1}$
}

\author{
Excmo. y Rvdmo. Sr. D. Juan José Asenjo Pelegrina \\ Arzobispo de Sevilla
}

1. El objeto de esta lección inaugural es precisar con exactitud la naturaleza del patrimonio cultural de la Iglesia, nacido para el culto y la gloria de Dios, y también para la evangelización y la catequesis, es decir, para anunciar a Jesucristo a nuestro mundo a través del camino de la belleza. Voy a hablar, pues, de la especificidad del patrimonio religioso. Al final, diré una palabra sobre Murillo, cuyo cuarto centenario está celebrando como se merece la ciudad de Sevilla.

2. Hace ya veinticinco años, siendo yo Delegado para el Patrimonio de la diócesis de Sigüenza y de su catedral, organicé un cursillo para un grupo de universitarios que pertenecían a una institución llamada Ars et fides, hoy Nartex, que se brindaron a enseñar la catedral en verano. En la primera sesión, pedí a dos participantes que me permitieran hacerles una prueba. Les dejé mi reloj. Disponían de un minuto para observar todos sus detalles. Pasado el minuto supieron decir al grupo la marca del reloj, el número de fabricación grabado en la tapa; y hasta las atmósferas de resistencia al agua, aunque figuraban en inglés. Pero lo que no habían observado era la hora que marcaba, es decir, la sustancia, la identidad más genuina, la razón de ser del reloj.

3. Esto es lo que puede ocurrir con algunos guías, restauradores y gestores del patrimonio, que conocen perfectamente el estilo de un retablo, el autor, la fecha de su labra, la suma de dinero que costó, la calidad del estofado, de los dorados y de la policromía y hasta el detalle de los quevedos de época que lleva san Lucas en muchos lienzos y tallas. Pero lo que sería imperdonable es que el guía, los gestores del patrimonio y los restauradores no supieran explicar el contenido y el mensaje de fe que encierra un retablo o una pintura, que es para lo que fueron hechos y por lo que se han conservado en nuestras iglesias. En este

1 Lección inaugural del Curso Académico 2018/19 del Centro de Estudios Teológicos de Sevilla, pronunciada el 4 de octubre de 2018. 
sentido sería muy necesario que todos ellos se acerquen a la iconografía desde la teología, o al menos desde la historia sagrada, que hoy por desgracia ya no se estudia, desde el Credo, en definitiva, que es la base de los programas iconográficos de nuestros bienes culturales.

4. El objeto de mi lección inaugural es, pues, precisar con exactitud la verdadera naturaleza del patrimonio cultural de la Iglesia. Se trata de un conjunto de bienes nacidos de la fe y de un impulso teologal. El patrimonio cultural de la Iglesia nace en primer término con una finalidad doxológica, es decir, de acuerdo con la etimología griega de la palabra, para la alabanza y la glorificación de Dios. Los bienes culturales de la Iglesia narran plásticamente la Historia de la Salvación, para que cuantos los contemplan se sientan movidos a la alabanza y glorificación del amor y la misericordia del Padre, que se nos ha manifestado en Jesucristo.

5. Los retablos e imágenes, iconos y lienzos están al servicio de este fin. La platería que labra los vasos sagrados y modela y repuja los ostensorios y custodias para la adoración del Santísimo, no tiene por finalidad la confección de objetos de arte cuyo único sentido es su propia belleza artística. Plata, oro y piedras preciosas tienen la función de mover a la glorificación y adoración del Señor, realmente presente en la Eucaristía².

6. La gloria de Dioses el móvil que explica el origen de nuestras catedrales, templos y retablos, más que las finalidades estéticas o decorativas. Así lo entendían patronos y mecenas, artistas y maestros, cuyo trabajo se ve sostenido por la fe del pueblo sencillo, convencido de que Dios merece siempre lo mejor. La participación admirable del pueblo cristiano en la edificación de los recintos religiosos se concretó en limosnas, donaciones de terrenos o materiales de construcción, o en prestaciones personales. Está bien documentado el fenómeno conocido como "la devoción de las carretas", que tuvo un auge extraordinario durante la construcción de la fachada principal de la catedral de Chartres en los comienzos del siglo XIII y que se extendió por toda Francia. En un clima penitencial, de fervor religioso, de cantos y rezos, hombres, mujeres y niños de humilde condición se aliaron con personajes de la nobleza y de la burguesía emergente para sustituir a los bueyes que tiraban de los carros que transportaban los materiales de construcción.

7. El alma de nuestras catedrales no se ciñe, pues, a su condición de yunque en el que se han forjado muchas ideas estéticas y estilos artísticos, ni en su condición de corazón de la ciudad y elemento imprescindible en la configuración y dinamización de los burgos medievales. La catedral no es simplemente la gloria

2 MONS. ADOLFO GONZÁLEZ MONTES, Discurso de Clausura de la Exposición «Luminaria. Dos milenios de cristianismo en Almería»,10 de noviembre de 2007. 
et splendor civitatis ${ }^{3}$, como calificara a la seo de Chartres un viejo cronista medieval. Es también y, sobre todo, la gloria et splendor Dei. A veces aparecen visiones prevalentemente económicas a la hora de programar las actuaciones tendentes a la conservación o restauración de los edificios religiosos. En ocasiones se habla de ponerlos en valor, expresión hoy de uso generalizado, apuntando casi siempre a los réditos económicos para el turismo o el comercio, que nunca pueden constituir un objetivo inmediato o preferente, sino más bien una secuela.

8. Pero, además, en el origen de nuestros tesoros artísticos hay una finalidad evangelizadora, aspecto consustancial a nuestros bienes culturales, que toda persona que tenga alguna relación con el patrimonio religioso no puede ignorar. Así ha sido a lo largo de los siglos, si exceptuamos el breve periodo de la crisis iconoclasta, siglo VIII y primera mitad del siglo IX. La Iglesia, en su acción evangelizadora ha recorrido siempre el camino de la belleza. Así lo reconocía Juan Pablo II en la Carta a los artistas de abril de 19994. Pero quien más ha reflexionado sobre la via pulchritudinis, antes y después de ser papa, ha sido Benedicto XVI, que nos ha pedido múltiples veces a los pastores no desdeñar en la pastoral el recurso a la belleza. Siendo todavía cardenal, en el meeting de Rímini de Comunión y Liberación en agosto de 2002, nos dejó esta idea verdaderamente luminosa: "la verdadera apología del cristianismo, la demostración más convincente de su verdad contra todo lo que lo niega, la constituyen, por un lado, los santos, y por otro la belleza que la fe ha generado. Para que hoy la fe se pueda extender, tenemos que conducirnos a nosotros mismos y guiar a las personas con las que nos encontramos al encuentro con los santos y a entrar en contacto con lo bello"5.

9. Hoy estas palabras cobran una especial actualidad. Efectivamente, la contemplación de la belleza es un recurso muy eficaz para evangelizar a un pueblo cada vez más alejado de las verdades de la fe. La belleza tiene más fuerza de transformación que la metafísica y la ética. Tiene también el poder de dignificar la vida de las personas. No se trata de recurrir al mero esteticismo, sino de subyugar con la belleza, que siempre constituye una forma superior de conocimiento, porque remite a la suprema belleza que es Cristo.

10. Los bienes culturales de la Iglesia surgieron, pues, también con una finalidad catequética. Los frescos de las catacumbas, de las basílicas paleocristianas, los mosaicos de las basílicas constantinianas de Roma, los iconostasios bizantinos, los frescos de las iglesias rupestres de Capadocia, o de las iglesias

3 Cfr. JUAN JOSÉ ASENJO PELEGRINA, Catedrales y monasterios patrimonio mundial. Seminario para el estudio de edificios Patrimonio Mundial de origen eclesiástico. Sevilla, 26 a 29 de noviembre, p. 21-26.

4 N.7.

5 JOSEPH RATZINGER, Caminos de Jesucristo, Cristiandad, Madrid 2004, p.39. 
mozárabes, por ejemplo san Baudelio de Casillas de Berlanga en la provincia de Soria, las pinturas de las iglesias románicas del Pirineo aragonés o catalán, de los santos Justo y Pastor y de san Clemente de Segovia, el pantocrator del ábside de san Clemente de Tahull, o la ermita de santa María de Arcos de Tricio en la Rioja, han sido para legiones de cristianos escalas de Jacob, puesto que les han llevado al conocimiento del evangelio.

11. Otro tanto cabe decir delas portadas románicas, las vidrieras góticas, y los grandes retablos góticos, renacentistas o barrocos, que han sido para muchos cristianos la litteraturalaicorum, el catecismo de los laicos, como se les llamó en la Edad Media, o el Evangelium pauperum, el Evangelio de los sencillos, de los iletrados, en feliz expresión de san Gregorio Magno en su carta a Sereno, obispo de Marsella, que en los años finales del sigloVI había mandado destruir las imágenes ${ }^{6}$.

12. El arte cristiano ha sido siempre la Biblia en piedra, en madera, o en metal con la que el pueblo cristiano, que mayoritariamente no sabía leer o escribir, aprendía las verdades fundamentales de la fe. El arte religioso ha sido a lo largo de la historia de la Iglesia una vía privilegiada de pedagogía de la fe.

13. Nuestros bienes culturales, en cualquiera de sus gamas, narran plásticamente la Historia de la Salvación, que ha sido su fuente de inspiración. Por ello, la iconografía cristiana puede ayudar al conocimiento de la Palabra de Dios y de las verdades de la fe, que han iluminado a los artistas. Hoy esto es más fácil que en épocas pasadas. Vivimos inmersos en la llamada cultura o idioma de la imagen. El hombre de hoy está más habituado que la generación de nuestros abuelos al lenguaje de las imágenes. Estas, en efecto, visualizan el misterio y nos aproximan a él. No es ocioso que recuerde, aunque sea muy de pasada la peripecia religiosa de tres ilustres conversos, que llegan a la fe por el camino de la belleza, dos franceses: Paul Claudel (1868-1955), poeta y diplomático ${ }^{7}$, André

6 Este es el texto del papa Gregorio, que muy pronto se hizo clásico: "Una cosa es adorar una pintura y otra servirse de una pintura para conocer a quien hay que adorar. Porque lo que un libro proporciona al que lo lee, eso es lo que una pintura ofrece a los analfabetos que la contemplan, pues en ella los ignorantes ven cómo tienen que comportarse, en ella leen los que no tienen letras" (Carta a Sereno: PL 77, 1128). Algo parecido afirma en Oriente el abad san Nilo de Ancira en los finales del siglo IV en carta a Olimpiodoro, prefecto de Constantinopla, que le pedía consejo sobre la decoración de las basílicas. Su consejo es el siguiente: "cubrir las paredes con narraciones del Antiguo y del Nuevo Testamento, pintadas por un buen pintor, de manera que los rudos e incapaces de leer las Sagradas Escrituras contemplen en figuras las obras realizadas por los que sirvieron a Dios y se estimulen a imitarlos"(Carta a Olimpiodoro: PG 79, 578-579, cit. por J. PlazAOLA, Historia y sentido del arte cristiano, BAC,Madrid 1996, 78-79).

7 Paul Claudel, en la mañana de Navidad de 1886, tratando de buscar argumentos para ridiculizar a la Iglesia, penetra en Notre Dame de París mientras se celebraba la Eucaristía. Algo debió sentir en su interior, pues volvió por la tarde mientras se cantaban las vísperas. Según él mismo confiesa, quedó subyugado por la majestuosidad del gótico catedralicio, por la música del órgano y por la belleza de lo que después él supo que era el Magnificat gregoriano, entonado por un coro de niños y el coro del Seminario de Saint Nicolas du Chardonnet. La belleza del templo, la música y 
Frossard (1915-1995) escritor y periodista ${ }^{8}$, y el filósofo español catedrático de metafísica en la Universidad central de Madrid, Manuel García Morente, convertido en su humilde pensión de exiliado en París el 29 de abril de 1937, mientras escuchaba en la radio la belleza sublime de la Infancia de Jesús de Héctor Berlioz, en este caso un bien cultural de naturaleza inmaterial e intangible ${ }^{9}$. Los

la dulzura del Adeste fideles final, le envolvieron de tal modo que su agnosticismo, como él mismo confesó más tarde, se vio repentinamente sumergido en la suprema belleza que destella el rostro de Cristo resucitado. En esa tarde Claudel supo que a partir de entonces su único hogar era la Iglesia católica. Así narra su conversión el propio Claudel:"Así era el desgraciado muchacho que el 25 de diciembre de 1886 fue a Notre-Dame de París para asistir a los oficios de Navidad. Entonces empezaba a escribir y me parecía que en las ceremonias católicas, consideradas con un diletantismo superior, encontraría un estimulante apropiado y la materia para algunos ejercicios decadentes. Con esta disposición de ánimo, apretujado y empujado por la muchedumbre, asistía, con un placer mediocre, a la Misa mayor. Después, como no tenía otra cosa que hacer, volvi a las Vísperas. Los niños del coro vestidos de blanco y los alumnos del pequeño seminario de Saint-Nicholas-du-Cardonet que les acompañaban, estaban cantando lo que después supe que era el Magnificat. Yo estaba de pie entre la muchedumbre, cerca del segundo pilar a la entrada del coro, a la derecha del lado de la sacristía. Entonces fue cuando se produjo el acontecimiento que ha dominado toda mi vida. En un instante mi corazón fue tocado y creí. Creí con tal fuerza de adhesión, con tal agitación de todo mi ser, con una convicción tan fuerte, con tal certidumbre que no dejaba lugar a ninguna clase de duda, que después, todos los libros, todos los razonamientos, todos los avatares de mi agitada vida, no han podido sacudir mi fe, ni, a decir verdad, tocarla. De repente tuve el sentimiento desgarrador de la inocencia, de la eterna infancia de Dios, de una verdadera revelación inefable. Al intentar, como he hecho muchas veces, reconstruir los minutos que siguieron a este instante extraordinario, encuentro los siguientes elementos que, sin embargo, formaban un único destello, una única arma, de la que la divina Providencia se servía para alcanzar y abrir finalmente el corazón de un pobre niño desesperado: "iQué feliz es la gente que cree! ¿Si fuera verdad? ¡Es verdad! ¡Dios existe, está ahí! ¡Es alguien, es un ser tan personal como yo! ¡Me ama! ¡Me llama!". Las lágrimas y los sollozos acudieron a mí y el canto tan tierno del Adeste aumentaba mi emoción". Cfr. PAUL ANDRÉ LESOR, Paul Claudel visto por sí mismo, Magisterio Español, Madrid 1970. A la conversión de Paul Claudel se refirió Benedicto XVI en una catequesis sobre Arte y oración en Castelgandolfo el 31 de agosto de 2011, con estas palabras: “¡Cuántas veces entonces las expresiones artísticas pueden ser ocasiones para que nos acordemos de Dios, para ayudar a nuestra oración o también a la conversión del corazón! Paul Claudel, famoso poeta, dramaturgo y diplomático francés, en la basílica de «Notre Dame» de París, en 1886, precisamente escuchando el canto del Magníficat durante la Misa de Navidad, percibió la presencia de Dios. No había entrado en la iglesia por motivos de fe; había entrado precisamente para buscar argumentos contra los cristianos, y, en cambio, la gracia de Dios obró en su corazón".

8 André Frossard, hijo del primer Secretario del partido comunista francés, educado en el más crudo ateísmo, encontró la fe cuando en una tarde de julio de 1935, entró en una pequeña iglesia del barrio latino de París buscando a un amigo y se encontró de bruces con Dios a través de la belleza, experimentando una alegría indescriptible, "una alegría -escribirá él después- que no es sino la exultación del salvado, la alegría del náufrago recogido a tiempo" Es el júbilo que experimentan todos los que se encuentran con Cristo Salvador. Este puede ser el camino de otros hombres y mujeres de buena voluntad que se acercan a nuestros bienes culturales. La Iglesia quiere tenderles la mano para que la belleza visible sea sacramento de encuentro con la belleza invisible de Dios,camino privilegiado que nos lleva a la libertad, la comunión y la felicidad (ANDRÉ FROSSARD, Dios existe, yo me lo encontré, Rialp, Madrid 1988).

9 Este es el relato delicioso de su conversión escrito por el propio filósofo con destino a su director espiritual, don José María García Lahiguera: "Algo exquisito, suavísimo, de una delicadeza y ternura tales que nadie puede escucharlo con los ojos secos... Cuando terminó, cerré la radio para no perturbar el estado de deliciosa paz en que esa música me había sumergido. Y por mi mente empezaron a desfilar-sin que yo pudiera ofrecerles resistencia-imágenes de la niñez de Nuestro Señor Jesucristo. Le vi, en la imaginación, caminando de la mano de la Santísima Virgen, o sentado en un banquillo y mirando con grandes ojos atónitos a San José y a María. Seguí representándome otros episodios de la vida del Señor: el perdón que concede a la mujer adúltera, la Magdalena lavando y secando los pies del Salvador, Jesús atado a la 
testimonios de estos tres conversos, son verdaderamente conmovedores y nos demuestran cómo Dios se sirve de la belleza para tocar el corazón.

14. La verdad es que la dimensión catequética del patrimonio no se impone sin lucha. Las primeras generaciones cristianas, deudoras todavía del judaísmo, profesan el aniconismo, es decir, se resisten a las representaciones figurativas. Pero muy pronto, a partir del año 200, se comienza a decorar con imágenes los lugares de reunión de los cristianos. El hecho de que el Concilio de Elvira, un Concilio extraordinariamente rigorista celebrado en el año 300 junto a Granada, lo prohíba ${ }^{10}$, es signo de que la costumbre iba afianzándose en las catacumbas, en las pequeñas iglesias del Asia Menor, en Hispania y, muy pronto, con la libertad de la Iglesia en el año 313, en baptisterios e iglesias del mundo mediterráneo, cuyas paredes se decoran con pinturas al fresco del Antiguo y Nuevo Testamento para la educación en la fe de los nuevos cristianos. Como curiosidad quiero decir que el primero que elaboró un programa iconográfico para enseñar las verdades de la fe a través de la belleza fue el poeta español, de Calahorra, Aurelio Prudencio, hacia el año 40011.

columna, el Cirineo ayudando al Señor a llevar la Cruz, las santas mujeres al pie de la Cruz... Y los brazos de Cristo crecían y crecían, y parecían abrazar a toda aquella humanidad doliente y cubrirla con la inmensidad de su amor, y la Cruz subía, subía hasta el cielo y llenaba el ámbito de todo y tras de ella subian muchos, muchos hombres y mujeres y niños; subian todos, ninguno se quedaba atrás; solo yo, clavado en el suelo, veía desaparecer en lo alto a Cristo rodeado por el enjambre inacabable de los que subían con Él; sólo yo me veía a mí mismo, en aquel paisaje ya desierto, arrodillado y con los ojos puestos en lo alto y viendo desvanecerse los últimos resplandores de aquella gloria infinita, que se alejaba de mí... ¿Y qué me había sucedido? Pues que la distancia entre mi pobre humanidad y ese Dios teórico de la filosofía me había resultado infranqueable. Demasiado lejos, demasiado ajeno, demasiado abstracto, demasiado geométrico e inhumano. Pero Cristo, pero Dios hecho hombre, Cristo sufriendo como yo, más que yo, muchísimo más que yo, a ése sí que le entiendo y ése sí que me entiende, a ése sí que puedo entregarle fielmente mi voluntad entera, tras de la vida. A ése sí que puedo pedirle, porque sé de cierto que sabe lo que es pedir y sé de cierto que da y dará siempre, puesto que se ha dado entero a nosotros los hombres. jA rezar, a rezar! $\Upsilon$ puesto de rodillas empecé a balbucir el Padrenuestro. $Y$ jhorror! ¡Se me había olvidado!... Lo primero que haré mañana será comprarme un libro devoto y algún buen manual de doctrina cristiana. Aprenderé las oraciones; me instruiré lo mejor que pueda en las verdades dogmáticas, procurando recibirlas con la inocencia del niño, es decir, sin discutirlas ni sopesarlas por ahora. Ya tendré tiempo de sobra, cuando mi fe sea sólida y robusta y esté por encima de toda vacilación, para reedificar mi castillo filosófico sobre nuevas bases. Compraré también los Santos Evangelios y una vida de Jesús. ¡Jesús, Jesús! ¡Misericordia! Una figura blanca, una sonrisa, un ademán de amor, de perdón, de universal ternura. iJesús!". Cfr. MANUEL GARCÍA MORANTE, El hecho extraordinario, Ed. Rialp, Madrid, 2002, p. 36-43.

10 Se trata del canon 36, cuyo tenor es el siguiente: "picturas in ecclesiis esse non debere, ne quod colitur et adoratur in parietibus depingatur"; es decir, "no debe haber pinturas en las iglesias, para que no se pinte en las paredes lo que se venera y adora". Cf. J.D. MANSI, Sacrorum conciliorum nova et amplissima collectio II, Florencia 1759, col. 1-19; M. Sotomayor y Muro, "La Iglesia en la España romana", en R. García Villoslada, Historia de la Iglesia en España, I, Madrid BAC, 1979, p. 1-400, esp. p. 111-113.

11 Dicho programa para la decoración de las basílicas, redactado en verso, es conocido con el nombre de "Dittochaeum". Consta de 48 títulos de historias, cada una con cuatro versos, a modo de rótulos explicativos para otras tantas escenas. Los 24 primeros son del Antiguo Testamento. Los otros 24 son escenas del Nuevo Testamento. En suma, se trata de plasmar al fresco una síntesis de la Historia de la Salvación, leyendo el Antiguo Testamento desde una perspectiva cristológica. 
15. Antes de seguir adelante, quiero subrayar la relación profunda entre la belleza, la bondad y el bien. El gran teólogo alemán Hans Urs von Balthasar en su obra cumbre Gloria, una estética teológica, afirma que nuestra palabra inicial se llama belleza... que es la aureola de resplandor imborrable que rodea a la estrella de la verdad y del bien"12. Efectivamente, la vía pulchritudinis nos conduce al encuentro con la verdad y con el bien, es decir con Dios, verdad primera, bien supremo y la hermosura misma. La vía de la belleza es capaz de tocar el corazón y disponerlo para el encuentro con Cristo, el más hermoso de los hijos de los hombres (Sal 45,2 ), siendo puente también para el encuentro con su Evangelio. La belleza artística suscita la emoción interior, provoca el silencio, el encantamiento, la salida de sí mismo, el éxtasis, donde la persona se encuentra como transportada fuera del mundo sensible por la intensidad del sentimiento experimentado. El documento final de la Asamblea del Pontificio Consejo para la Cultura del año 2006, tituladola Via Pulchritudinis, camino de evangelización y de diálogoafirma que la via pulchritudinis"invita a los nuevos Agustín de nuestros días, a los buscadores insaciables del amor, de la verdad y de la belleza, a elevarse desde la belleza sensible a la Belleza eterna y a descubrir con fervor al Dios Santo, al autor de toda belleza".

16. A veces podemos sentir un cierto pudor a la hora de concebir y hacer operativa la misión evangelizadora de nuestros bienes culturales. A veces, en las grandes exposiciones organizadas por la Iglesia en los últimos treinta años el mensaje que queremos transmitir es tan implícito que se torna ininteligible, al menos para el pueblo sencillo. En otras ocasiones, destacamos sólo el servicio que la Iglesia ha prestado secularmente a la cultura o a los necesitados, o concebimos la visita cultural como una mera pre-evangelización, aplazando sine die, el anuncio explícito de Jesucristo. En la exhortación apostólica Evangelii nuntiandi nos dejó escritoel papa Pablo VI que "no hay evangelización verdadera mientras no se anuncie el nombre, la doctrina, la vida, las promesas, el reino y el misterio de Jesús de Nazareth, Hijo de Dios" ${ }^{\prime 13}$. No es ocioso traer aquí el testimonio de un teólogo protestante, D. Bonhoeffer, ahorcado por la Gestapo poco antes del final de la Segunda Guerra Mundial al descubrirse que estaba involucrado en una conspiración para asesinar a Hitler: "No hay mayor impiedadque ofrecer al mundo algo menor que Jesucristo".

17. Nos encontramos con otro obstáculo: La fe cristiana ha sido capaz de crear una cultura exuberante, la cultura cristiana. Ha sido, pues, un manantial de creatividad artística de primer orden. Por ello, la secularización, la desertización espiritual y la crisis del hombre, temas todos sobre los que ha reflexionado con profusión el papa Benedicto XVI, constituye hoy una inmensa pérdida para la

12 H. U.VON BALTHASAR, Gloria, una estética teológica, Madrid, Encuentro, Madrid 1985, p. 22.

13 N. 22. 
cultura y el arte. Así lo sentía también el pintor Vasili Kandinsky (1866-1944), en su obra "De lo espiritual en el arte". En ella lamentaba que la decadencia espiritual ha conducido a la decadencia en el mundo del arte y a la exaltación de lo feo ${ }^{14}$. En lecturas recientes me he encontrado con algunos autores que manifiestan un malestar indisimulado ante la fealdad artística que ha invadido los nuevos templos en las últimas décadas ${ }^{15}$. Consideran además que la fealdad artística no es solo un fracaso del arte, sino también un tránsito a la falsedad, dada la íntima relación entre belleza y verdad. Por lo mismo, la fealdad empobrece o impide la experiencia religiosa, puesto que propicia la incomunicación no solo con la verdad, sino también con la bondad y, en consecuencia, con el misterio de Dios.

18. En su obra El idiota ${ }^{16}$, novela publicada en 1868, Dostoievski profetizaba que "la belleza salvará al mundo". No se trata de una pretensión excesiva, porque el arte tiene entre otras la función de inyectar dosis de alma en las venas del mundo. El encuentro con la belleza nos saca de nosotros mismos, nos eleva por encima de nuestras miserias y nos enseña a habitar en el mundo asombrándonos ante la belleza de nuestra vida y de nuestra historia. Por eso es tan necesario reanudar el diálogo de la Iglesia con los artistas, interrumpido por razones ideológicas a raíz de la Ilustración y por razones económicas como consecuencia de las Desamortizaciones de los bienes eclesiásticos. Es necesario también acompañar a los verdaderos artistas, porque si son capaces de vislumbrar en la belleza del mundo un destello de la belleza divina, entonces el arte abre un puente hacia la transcendencia, un camino hacia Dios que el hombre es invitado a recorrer. Así lo afirmaba el papa Juan Pablo II en la citada "Carta a los artistas". De este modo, el arte se convierte en un lazarillo que nos lleva de la mano hacia Dios, como escribiera san Juan Damasceno en el siglo VIII ${ }^{17}$.

19. Más modernamente el escritor alemán Hermann Hesse, premio Nobel de Literatura en 1946, afirmaba categóricamente que "arte significa: dentro de cada cosa mostrar a Dios"18. Algo parecido escribió la filósofa judía Simone Weil $(1909-1943)^{19}$. Por su parte, el escritor inglés Clive S. Lewis, fallecido en Oxford

14 VASILI KANDINSKY, De lo espiritual en el arte: contribución al análisis de los elementos pictóricos, Paidós Ibérica, Madrid, 1996.

15 "Ese malestar es producto de una atmósfera viciada, y lo que vicia esa atmósfera es la fealdad. En las iglesias lo que respiramos es fealdad" (F. PÉREZ GUTÍERREZ, La indignidad en el arte sagrado, Madrid 1961, p. 19. Cfr. AURELIO GARCÍA MACÍAS, Arte y liturgia: Per viam pulchritudinis, Valladolid 2014, p, 27).

16 Publicada en 1868, III, cap.V.

17 Sermón II de las Imágenes: PG 94, 1336.

18 Cfr. AURELIO GARCÍA MACÍAS, Arte y liturgia: Per viam pulchritudinis, Valladolid 2014, p, 34.

19 "En todo lo que suscita en nosotros el sentimiento puro y auténtico de la belleza está realmente la presencia de Dios. Existe casi una especie de encarnación de Dios en el mundo, cuyo signo es la belleza. Lo bello es la prueba experimental de que la encarnación es posible. Por esto, todo arte de primer orden es, por su esencia, religioso". Cfr. AURELIO GARCÍA MACÍAS, Arte y liturgia: Per viam pulchritudinis, Valladolid 2014, p, 34. 
en 1963, nos dejó escrito que la belleza despierta la nostalgia de "nuestra patria lejana". [...] La belleza hace llegar hasta nosotros una ráfaga [una bocanada de aire] del Reino. [...]. El arte se torna así en un servicio a la evangelización y el artista, en un misionero y un don para el mundo.

20. Una vez más quiero repetir que el patrimonio cultural de la Iglesia, es decir, la belleza nacida de la fe y del manantial límpido y fecundo del Evangelio, tiene un valor evangelizador incontestable. Bien aprovechado es un puente tendido hacia la experiencia religiosa. Que esto no es una quimera y que el arte verdadero tiene capacidad para suscitar la nostalgia de Dios y de lo religioso lo demuestra la historia de los tres conversos que he mencionado. Este es también el caso del filósofo personalista francés Gabriel Marcel (1889-1973), que confiesa la importancia excepcional que las Pasiones y cantatas de Juan Sebastián Bach ejercieron en su conversión y en su vida cristiana posterior ${ }^{20}$. También para él la música fue la porta fidei, la puerta que le condujo a la fe.

21. Lo que decimos de las artes plásticas y de la música, puede decirse igualmente de la liturgia, que bien celebrada es arte, el ars celebrandi del que nos ha hablado con frecuencia Benedicto XVI. Es el servicio de la mistagogía, palabra griega bien conocida en la tradición eclesial, que designa la tarea de introducir a los fieles en los divinos misterios que se celebran en la liturgia, pasando de lo visible a lo invisible, del signo a lo significado, de los sacramentos a los misterios ${ }^{21}$. La liturgia celebrada con una solemnidad no efectista, en una iglesia hermosa, con la sobriedad y la sencillez de lo auténtico, y mucho más si está acompañada por una música bella y el acompañamiento de un órgano de tubos, es verdadera cultura, facilita el encuentro con el misterio, acerca Dios y abre el camino a lo transcendencia.

22. Es poco conocido el caso del Cardenal Lustiger, Arzobispo de Paris, polaco judío. Siendo todavía adolescente, como consecuencia de la persecución de los judíos en la Segunda Guerra Mundial, tuvo que huir con su familia a Orleans, escenario de su conversión. Un cierto día, que después él supo que era Jueves Santo, entró en la catedral. La impresión que le produjo el monumento, lleno de luces, flores, y fieles que acompañaban al Santísimo con fervor, hizo que volviera al día siguiente, Viernes Santo. La piedad del pueblo, el silencio y la belleza del gótico catedralicio le envolvieron y el Señor tocó su corazón. Ese mismo día decidió pedir el bautismo 22 .

20 Cfr. ALFONSO LÓPEZ QUINTÁS, La filosofía de Gabriel Marcel, publicado en ABC el 10 de febrero de 1974, p 149. Cfr. También el interesantísimo artículo de MIGUEL ÁNGEL GARCÍA OLMO, titulado Belleza tan antigua y tan nueva... publicado en Arvo.net.

21 Catecismo de la Iglesia católica, n. 1075.

22 J. M. LUSTIGER. La elección de Dios. Entrevistas realizadas por Jean Louis Missika y Dominique Wolton, Barcelona 1989, p. 36. 
23. Antes de terminar, y sin despreciar otros aspectos en los que no me puedo detener ${ }^{23}$, y teniendo en cuenta que estoy hablando a seminaristas, quiero concluir con algunas consideraciones de carácter práctico. Quiero decir en primer lugar que no siempre se ha valorado la dimensión pastoral del trabajo del sacerdote preocupándose del patrimonio inmueble y mueble. A veces se ha considerado como una actividad de segundo nivel por no tener aparentemente un marchamo directamente pastoral. Yo quiero subrayar que es en primer lugar un testimonio de fe por parte del sacerdote, celoso de la gloria de Dios, convencido de que el Señor merece una casa bella, limpia y ordenada. El cuidado del patrimonio es también un servicio a nuestro pueblo, ayudándole a conservar

23 Me refiero en primer lugar a la perspectiva apologética, un aspecto de la teología que, en las últimas décadas, no ha gozado de excesivas simpatías. Hoy, sin embargo, no faltan teólogos que reclaman la vuelta a la apologética, que en la coyuntura actual es más necesaria que nunca. En este sentido, el Plan Pastoral de la Conferencia Episcopal Española para el cuatrienio 19941997, titulado "Para que el mundo crea" (Jn 17,21), nos decía que "es importante tener en cuenta que la evangelización en una sociedad poscristiana y neopagana, tiene que tener permanentemente una dimensión apologética" (n. 9-10). Según este documento de nuestra Conferencia Episcopal, la dimensión apologética hoy "resulta indispensable". Puede tener exigencias diversas según sean las ideas dominantes respecto de la Iglesia, la jerarquía, la religión o Dios mismo: el anticlericalismo clásico fundado casi siempre en prejuicios, las dificultades de orden intelectual o la tendencia a calificar a la religión como una "actividad primitiva, infundada y perniciosa" para el desarrollo de la persona y de la sociedad, enemiga de la razón, de la libertad y del progreso. En el contexto actual, en la visita turística no deberíamos despreciar una cierta tonalidad apologética, para deshacer malentendidos, aclarar nociones deformadas y superar actitudes de menosprecio ante lo religioso. Esta tarea habrá de realizarse con discreción, casi imperceptiblemente, sin espíritu polémico, con un estilo de diálogo y servicio, mostrando de manera directa y humilde el don de la salvación que Dios ofrece en Jesucristo, también a los hombres y mujeres de hoy, sin otro poder que el de su gracia y sin otra sabiduría que la de la Cruz redentora de Cristo, pues como se dice en el citado documento, "el testimonio definitivo que invita a la fe es el de la vida, muerte y resurrección de Jesucristo, con la vida y muerte de sus mejores discípulos que son los santos" (n. 10). La evangelización con los santos, que con tanta profusión y belleza se muestran en nuestros museos, es el segundo aspecto que quisiera destacar. En los últimos años, desde algunas instancias mediáticas se ha calificado reiteradamente a nuestras obras sociales y caritativas como "las joyas de la corona" de la Iglesia. Sin despreciar a estas instituciones, que son orgullo de nuestra Iglesia, las verdaderas joyas de la corona son los santos. Efectivamente, ellos son los hijos más preclaros de la Iglesia, ellos hacen inteligible y creíble el Evangelio. Una prueba evidente es la simpatía universal que ha provocado en los últimos años la figura, la muerte y la beatificación y canonización de la Madre Teresa de Calcuta y la agonía y fallecimiento del papa Juan Pablo II. Los santos embellecen el rostro de la Iglesia, en el que si es cierto que hay sombras y arrugas por los pecados y deficiencias de sus miembros, es también cierto que la luz es más intensa que las sombras y que el heroísmo de los santos, nuestros hermanos, es más fuerte que nuestro pecado y nuestra mediocridad. "El hombre de hoy -escribió Pablo VI hace más de treinta años- presta más atención a los testigos que a los maestros; o si escucha a los maestros, lo hace porque son testigos" (Discurso al Consilium de laicis, 2, X1, 1974).Los santos pueden constituir un signo cargado de interrogantes profundos para los que no creen, una interpelación y, en ocasiones, un camino para descubrir el rostro de Dios, que se ha encarnado y ha tomado forma en los rostros y en las vidas de aquellos que han hecho de Cristo la razón de su propia existencia. Mostrar tanta hermosura, la santidad de la Iglesia, es hoy, sin duda, un excelente camino de evangelización, un motivo de credibilidad, que es especialmente luminoso y atrayente en el caso de los mártires de los primeros siglos, de los siglos posteriores y, sobre todo, de los mártires del siglo XX, tan próximos a nosotros cronológica y existencialmente. 
sus raíces religiosas, históricas y culturales. Es además un servicio a la evangelización. Anunciar a Jesucristo es la razón última que acredita y legitima el servicio al patrimonio. Organizar un museo allí donde se pueda es un servicio verdaderamente misionero, porque el patrimonio artístico es frecuentemente el único eslabón que une con la Iglesia, a través de la visita cultural, a los que no creen, a los alejados y a tantos hermanos que han abandonado la fe o la práctica religiosa en los últimos años.

24. Para ello, se necesita valentía, audacia y caridad pastoral en los responsables, delegados diocesanos, directores de museos, párrocos o canónigos. Se necesita también imaginación para articular un discurso discreto, respetuoso y alejado del proselitismo, pero al mismo tiempo explícito, sin complejos, atractivo y convincente en la palabra de los guías y demás técnicas de intermediación. No basta crear museos. Es preciso dotarles de una impronta evangelizadora, para que sean, como dice el documento tantas veces citado del Pontificio Consejo para la Cultura, "nuevas epifanías de la belleza".

25. La Comisión Episcopal para el Patrimonio Cultural ha sugerido muchas veces la urgencia de crear en todas las diócesis escuelas de guías del patrimonio. Se ha pedido también asegurar su formación artística, teológica y catequética, cuidando que sean personas de Iglesia, de una identidad cristiana neta, con vigor apostólico, verdaderamente convencidas de la importancia de su labor y capaces de acoger al visitante con respeto y calor, pues a la Iglesia nadie debe ganarle en humanidad. Cuando se trata de mostrar un templo, ellos deben ser los primeros convencidos de su sacralidad, de su condición de espacio vivo, porque es el lugar de reunión de la asamblea, donde cada día se realiza el milagro de la Eucaristía y donde consiguientemente se encuentra el Señor, de manera que el visitante se sienta invitado a participar en el misterio.

26. En la tarea de aprovechar las potencialidades evangelizadoras de nuestro patrimonio chocamos con una dificultad fundamental, la secularización de la sociedad, impermeable ante lo religioso, y las presiones que la Iglesia recibe cada día de determinadas instancias para que despoje su discurso de referencias a la fe, pretensión ésta contraria a toda lógica, puesto que una obra de arte que ha surgido por y para la fe no puede entenderse sin apelar a la fe que la creó. Efectivamente, el creciente debilitamiento del sentido sagrado del patrimonio religioso, fruto de la secularización que a todos nos envuelve, tiende a considerar únicamente los aspectos estéticos y culturales de estos bienes o su dimensión económica como generadores de riqueza.

27. La Iglesia no niega tales valores culturales, ni sus potencialidades turísticas o incluso económicas, que en todo caso serán una redundancia, pero que nunca podrán ser las finalidades decisivas.Y digo esto a propósito de algunas instituciones 
públicas, que están elaborando programas de explotación cultural y turística de algunas catedrales prescindiendo de su significación y destino religioso ${ }^{24}$. En el fondo, se parte de la base de que lo religioso es algo que pertenece al pasado, a una fase superada de la historia de la humanidad ${ }^{25}$, estando inevitablemente condenado a extinguirse.

28. Tales planes, que ignoran completamente la identidad propia del monumento, en este caso la catedral, entrañan una notable perversión, puesto que la degradan y envilecen. La finalidad de una catedral es muy otra: la gloria de Dios, el culto solemne, la oración, la evangelización y su condición de cátedra del obispo, finalidades todas ellas que justifican su existencia antes y mejor que cualquier otra consideración, todo lo cual entraña una dimensión cultural incontestable ${ }^{26}$.

29. En la parte final de mi intervención, quiero decir una palabra sobre Murillo en el IV centenario de su nacimiento. Soy consciente de que existen intentos de secularizar la figura de Murillo. Por ello, ante todo manifiesto mi convicción de que Bartolomé Esteban Murillo fue un pintor de mucha hondura religiosa, muy consciente de la fuerza evangelizadora de su pintura. Basta rastrear sus presupuestos existenciales y sus convicciones más íntimas. Murillo fue

24 En el año 1999 la Consejería de Cultura de un gobierno regional presentó al obispo de una diócesis española todo un plan de "explotación cultural y turística" de una importante catedral, cuya gestión estaría encomendada a una Fundación al margen del Cabildo y en la que la Iglesia sólo estaría simbólicamente representada. El plan incluiría la creación de un centro de interpretación del edificio y de sus bienes culturales. En la propuesta no se negaba el carácter sagrado del templo. El culto, sin embargo, quedaba relegado a las primerísimas horas de la mañana o a las ultimísimas de la tarde. En el entretanto se pensaba convertir la Catedral en un gigantesco museo, casi un parque temático, con una perspectiva muy alejada de su origen y de su significación primigenia. Otro tanto ocurrió en el año 2007 en una Diócesis castellana. La Consejería de Cultura correspondiente presentó todo un plan de explotación turística de un importante conjunto de iglesias románicas, elaborado por un conocido arquitecto. En dicho Plan se olvidaba a la titularidad y se prescindía de la significación religiosa de los edificios. $\mathrm{Ni}$ que decir tiene que ambos planes fueron rechazados por los obispos respectivos. Algo parecido, e incluso con más ambición y escaso respeto, se ha proyectado en el año 2017, por el Ayuntamiento de Zaragoza en relación con varios edificios religiosos emblemáticos de la ciudad.

25 Con todo, a mi modo de ver, la mayor dificultad es intraeclesial y tiene un nombre, la secularización interna, que es la raíz fundamental de los problemas de nuestra Iglesia en esta hora, una realidad fatal que hay que superar mediante la conversión personal y también mediante la necesaria conversión pastoral. La secularización interna básicamente consiste en bajar los niveles, en adoptar estilos pastorales irenistas o contemporizadores con la nueva cultura, para no entrar en confrontación con los dogmas seculares del momento, evitando provocar y herir susceptibilidades, para no hacer repulsivo el Evangelio. Refiriéndome ya a nuestros bienes artísticos y a su primordial función evangelizadora, quiero decir que es verdad que el actual contexto cultural nos condiciona, pero no podemos dejar que nos marque la perspectiva, mimetizándonos con la nueva cultura, apuntando a un ideal de mínimos y desconfesionalizando la visita a nuestras catedrales y museos que, ante todo, deben ser hogares de la fe y de evangelización.

26 A esta dimensión se refería en mayo del año 2000 don Fernando Chueca Goitia en un magnífico artículo publicado en $\mathrm{ABC}$ con el título "La religiosidad y la arquitectura moderna". 
esencialmente, aunque no exclusivamente, un pintor religioso, faceta que conocieron en gran medida los arzobispos, el cabildo hispalense, con el que colaboró durante treinta años, y las instituciones religiosas de la ciudad, sobre todo la Hermandad de la Santa Caridad. Fue amigo de muchos miembros de la corporación capitular sevillana, singularmente de Justino de Neve. Por otra parte, fue grande su cultura religiosa. Pero, sobre todo, a su genio artístico indiscutible, Murillo unió una fe sincera y una piedad no fingida, todo lo cual le confirió una clara afinidad o con naturalidad con la verdad revelada, el sentido sobrenatural de lo divino, el "sensus fidelium", del que hablan los teólogos, que Dios concede a quienes viven cerca de Él con sencillez de corazón.

30. Porque nadie da lo que no tiene, yo estoy convencido que sólo la profunda religiosidad de Murillo explica unas obras que rezuman una extraordinaria unción religiosa y que nos muestran la visión de un cielo amable, claro y límpido; que nos descubren también lo etéreo de esos rompimientos de gloria que conectan el cielo con la tierra, que unen a Dios con el hombre. Murillo nos brinda además la belleza de las manos y los rostros de sus inmaculadas, de las santas Justa y Rufina, de los ángeles que sirven de escabel a sus purísimas y la mirada de la santidad de san Fernando en el cuadro pintado con ocasión de su canonización en 1671, todo lo cual es capaz de tocar el corazón de quienes contemplan sus obras sin prejuicios ni corazas, intuyendo en la belleza visible, la belleza invisible de Dios.

31. No se puede dudar de la profunda religiosidad de Murillo, miembro de las Hermandades del Rosario y de la Vera Cruz, miembro también de la Tercera Orden de san Francisco y de la Santa Caridad, en la que fue admitido en 1665 por su fundador, elVenerable Miguel Mañara, con el que mantuvo una estrecha y sincera amistad. En el año 1650 Mañara apadrina a la hija del pintor Isabel Francisca, y al año siguiente a su hijo Francisco Miguel. Mañara y Murillo sintonizaron por entero en el meollo de la vida cristiana, en la caridad teologal hacia Dios y en la caridad con el prójimo, especialmente los pobres, los enfermos y los necesitados para los que Mañara funda la Hermandad y el Hospital de la Santa Caridad. Ambos habían leído en la primera carta de san Juan que "nadie puede decir que ama a Dios a quien no ve, si no ama al prójimo a quien ve" (1 Jn 4,20). Ambos habían leído en los Dichos de luz y amor de san Juan de la Cruz que "en la tarde de la vida te juzgarán del amor". De ahí su compromiso cristiano y su compromiso fraterno.

32. Mañara, y con él Murillo, estaba convencido de la misteriosa identificación de Jesús con los pobres y los enfermos, en los que ve el rostro doliente del Señor. Por ello, encarece a sus hermanos de la Santa Caridad la necesidad de asistir a los enfermos no desde la lejanía, sino desde la cercanía y la inmediatez 
corporal, lavando, curando y besando sus llagas, pues como él mismo escribe "debajo de aquellos trapos está Cristo pobre, su Dios y Señor"27. Esta es también la convicción del papa Francisco: En la vigilia de Pentecostés de 2013 pregunta a los representantes de los movimientos eclesiales: «Y cuando das la limosna, ¿tocas la mano de aquel a quien le das la limosna, o le echas la moneda?». A continuación el Papa nos invitaba a ver y tocar en los pobres y enfermos la carne de Cristo, tomando sobre nosotros el dolor de los pobres ${ }^{28}$. Como afirma Pedro Hereza, desde esta persuasión de la misteriosa identificación de Cristo con los pobres, Murillo acepta gustoso los exigentes códigos morales que Mañara impuso a sus hermanos como fundador de la Santa Caridad. Entre otras muchas prescripciones, los hermanos estaban obligados, a pedir limosna para los pobres en la puerta de San Miguel de la catedral y en las iglesias en que se celebraba jubileo todos los domingos y fiestas, y consta que Murillo cumplió escrupulosamente esta obligación.

33 El profesor Diego Angulo Íñiguez asegura que cuando Murillo ingresa en la Caridad en 1665, en la documentación para justificar su entrada se especifica que "será muy del servicio de Dios Nr. Sr. y de los pobres, tanto para su alivio como por su arte para el adorno de nuestra capilla"29. Es más que probable que Mañara y Murillo concibieran conjuntamente el programa iconográfico de las obras de misericordia, que Murillo llevará a los lienzos. Es seguro que en la mente de ambos el proyecto tenía una finalidad catequética y evangelizadora. Mañara lo manifestó más de una vez. El encargo debió efectuarse en el citado año 1665 quedando concluido en 1670. Como es bien sabido, las obras de misericordia son catorce, siete corporales y siete espirituales. El programa iconográfico se centra en las corporales: visitar a los enfermos, dar de comer al hambriento, dar de beber al sediento; dar posada al peregrino; vestir al desnudo; socorrer a los presos y enterrar a los muertos. Las seis primeras fueron pintadas por Murillo. La séptima no es lienzo. Es una talla soberbia, el entierro de Cristo, emplazada en el retablo mayor, debida a la gubia de Pedro Roldán y policromada por Valdés Leal a partir del año 1670.

34. De los seis lienzos sólo dos se hallan en su destino originario, la capilla de San Jorge, la segunda y la tercera de las obras de misericordia, que llevan como título la Multiplicación de los panes y los peces y Moisés haciendo manar el agua de la roca del Horeb, justamente las dos obras restauradas recientemente

27 MIGUEL MAÑARA, Renovación de la Regla, 7. Cfr. FRANCISCO MARTíN HERNÁNDEZ, Miguel de Mañara, Universidad de Sevilla 1981, p. 164.

28 Vigilia de Pentecostés con los Movimientos Eclesiales, Palabras del Santo Padre Francisco, Plaza de san Pedro, sábado 18 de mayo de 2013.

29 DIEGO ANGULO ÍÑIGUEZ, Murillo: su vida, su arte, su obra, Madrid, España Calpe, 1981, vol. I, 80. Cfr. BENITO NAVARRETE PRIETO, Murillo y las metáforas de la imagen, Madrid, Cátedra, 2017, 251. 
por el Instituto Andaluz del Patrimonio Histórico. Los otros cuatro lienzos se inscriben en la relación fatal de los cuadros expoliados por el mariscal Soult, de infausta memoria, autor de la mayor catástrofe cultural acaecida en la historia de Sevilla ${ }^{30}$. Me refiero a la primera de las obras de misericordia, la curación del paralitico de la piscina de Bethesda; la cuarta, Abraham y los tres ángeles; la quinta, el regreso del hijo pródigo; y la sexta, la liberación de san Pedro. Los cuatro se encuentran en pinacotecas extranjeras ${ }^{31}$.

35. Insisto de nuevo en mi convicción de que Murillo confería a sus obras una finalidad didáctica y evangelizadora e, incluso, una finalidad apologética. Él se insertó de lleno en el movimiento que propugnaba en la Sevilla de la primera mitad del siglo XVII la definición dogmática de la Inmaculada Concepción. Sus diecinueve inmaculadas lo atestiguan. Aunque nacido en 1617, tuvo necesariamente que conocer lo que Domínguez Ortiz llamó el estallido inmaculista, provocado en la fiesta de la natividad de laVirgen de 1613 por un sermón predicado por el P. Diego de Molina, prior del convento dominico de Regina Angelorum, que manifestó alguna duda sobre la concepción sin mancha de la Santísima Virgen apoyándose en santo Tomás.

36. La reacción no se hizo esperar. El pueblo sencillo de Sevilla mostró con vehemencia su oposición. Los cronistas de la época, como atestigua Domínguez Ortiz, nos dicen que la conmoción popular durante varias semanas provocó incluso problemas de orden público. La abundancia y exuberancia de las inmaculadas de Murillo tiene seguramente mucho que ver con la pasión con que vivió Sevilla la prehistoria del dogma inmaculista. Tales inmaculadas fueron el referente visual y plástico de una fe en la concepción inmaculada de la Virgen que creció incesantemente en Sevilla, ciudad mariana por excelencia, que tanto contribuyó a la declaración dogmática del papa Pío IX de 8 de diciembre de 1854.

38. Termino ya agradeciendo a todos su atención. Si he conseguido ayudarles a descubrir las potencialidades evangelizadoras de nuestro patrimonio y su verdadera identidad, habré cumplido el objetivo principal de mi intervención, pues anunciar a Jesucristo a través de los bienes culturales es el mejor servicio que podemos prestar a nuestros conciudadanos, compartiendo con ellos el mejor tesoro que posee la Iglesia, Jesucristo, "centro de la humanidad, gozo del corazón humano y plenitud total de sus aspiraciones", en expresión feliz del Concilio Vaticano II $^{32}$.Como

30 ENRIQUEVALDIVIESO GONZÁLEZ, El expolio artístico de Sevilla durante la invasión francesa, Boletín de la Real Academia Sevillana de Buenas Letras, 37 (2009), p. 261-267.

31 La curación del paralitico de la piscina de Bethesda se encuentra en la National Gallery de Londres; Abraham y los tres ángeles, en laNational Gallery de Ottawa; el regreso del hijo pródigo, en laNational Gallery de Washington; y la liberación de san Pedro, en el Museo del Hermitage de San Petersburgo Cfr. NAVARRETE, o. c., p. 245-246.

32 Constitución pastoralGaudium et spes, 45. 
nos dijera el papa Benedicto XVI en la inauguración de la Asamblea del CELAM en Aparecida (Brasil) en mayo de 2007, nosotros los cristianos sabemos mejor que nadie que sin Cristo no hay luz, no hay esperanza, no hay amor, no hay futuro para el mundo ${ }^{33}$.Los obispos latinoamericanos y del Caribe, por su parte, en el mensaje final de aquella Asamblea, añadieron que Él"es la respuesta total, sobreabundante y satisfactoria a las preguntas humanas sobre la verdad, el sentido de la vida, la dignidad humana, la felicidad, la justicia y la belleza"33. Muchas gracias.

33 Palabras pronunciadas en la inauguración de la Asamblea del CELAM, en Aparecida (Brasil) en mayo de 2007, recogidas en declaración final de la Asamblea, n.146.

34 El texto pertenece a la Declaración final, capitulo 8, titulado Reino de Dios y promoción de la dignidad humana, n.380. 